\title{
Antigenic characterization of Trypanosoma evansi using sera from experimentally and naturally infected bovines, equines, dogs, and coatis
}

Caracterização antigênica do Trypanosoma evansi usando soros de bovinos, equinos, cães e quatis experimentalmente e naturalmente infectados

Lúcia Padilha Cury Thomaz Aquino'; Rosangela Zacarias Machado ${ }^{1 *}$; Karen Regina Lemos ${ }^{1}$; Luiz Carlos Marques ${ }^{1}$; Marcos Valerio Garcia ${ }^{1}$; Gustavo Puia Borges ${ }^{1}$

${ }^{1}$ Faculdade de Ciências Agrárias e Veterinárias, Universidade Estadual Paulista - UNESP

Received May 18, 2009

Accepted June 16, 2009

\begin{abstract}
The present research investigated the presence of T. evansi antibodies in animals from the subregion of Nhecolandia, in the Pantanal Sul-mato-grossense, by means of an enzyme linked immunosorbent assay (ELISA) and indirect immunofluorescence antibody test (IFAT), and the pattern of polypeptide recognition by sera from experimentally and naturally infected hosts using Western blotting. Serum samples were obtained from bovines $(\mathrm{n}=102)$, horses $(\mathrm{n}=98)$, and dogs $(\mathrm{n}=55)$, and from 32 free-ranging coatis (Nasua nasua). None of the bovines were found positive, while sera from 16 dogs $(29 \%)$ and 23 horses (23.4\%) were positive by ELISA. Sera from 8 coatis (25\%) were found positive using IFAT. Western blotting revealed major polypeptides of $T$. evansi with molecular weight ranging from 74 to $38 \mathrm{kDa}$. The polypeptides of $66,48-46$, and $38 \mathrm{kDa}$ were identified by sera from experimentally infected bovines, donkeys, dogs, and coatis. The 48-46 and $38 \mathrm{kDa}$ bands were mainly recognized in chronic phase of infection. The antigen with apparent molecular weight of $66 \mathrm{kDa}$, revealed by antibodies from all experimental animals, was also recognized in sera of horses and dogs from the Pantanal. The 48-46 kDa polypeptide was identified by antibodies from all naturally infected animals and must be further evaluated for use in specific diagnosis of $T$. evansi infection.
\end{abstract}

Keywords: Trypanosoma evansi, ELISA-test, IFAT, Pantanal mato-grossense, antigenic characterization.

\section{Resumo}

O trabalho de pesquisa investigou a presença de anticorpos anti- T. evansi em animais da sub-região da Nhecolândia, no Pantanal sul-mato-grossense, pelo ensaio imunoenzimático (ELISA) e a reação de imunofluorescência indireta (RIFI). O reconhecimento de polipeptídeos de T. evansi foi realizado pela técnica de "Western blotting", utilizando soros de animais experimentalmente e naturalmente infectados. As amostras de soro foram obtidas de bovinos $(\mathrm{n}=102)$, cavalos $(\mathrm{n}=98)$ e cáes $(\mathrm{n}=55)$ e de 32 quatis de vida livre (Nasua nasua) do pantanal mato-grossense. Todos os soros dos bovinos foram negativos, enquanto soros de 16 cáes $(29 \%)$ e 23 cavalos $(23,4 \%)$ foram positivos pelo ELISA. Soros de oito quatis $(25 \%)$ foram positivos pela RIFI. Pelo "Western-blotting" foi possível revelar polipeptídeos de T. evansi, com peso molecular variando de 74 a $38 \mathrm{kDa}$. Os polipeptídeos de 66, 48-46 e $38 \mathrm{kDa}$ foram identificados por soros de bovinos, cavalos, cães e quatis experimentalmente infectados. As bandas de $48-46$ e $38 \mathrm{kDa}$ foram reconhecidas principalmente na fase crônica da infecçáo. O antígeno com peso molecular aparente de $66 \mathrm{kDa}$, revelado por anticorpos de todos os animais experimentais, também foi reconhecido por soros de cavalos e cães do Pantanal. O polipeptídeo de $48-46 \mathrm{kDa}$ foi identificado por anticorpos de todos os animais naturalmente infectados, devendo ser avaliado para o diagnóstico específico da infecção pelo T. evansi.

Palavras-chave: Trypanosoma evansi, ELISA-teste, RIFI, Pantanal mato-grossense, antigenic characterization.

\footnotetext{
${ }^{*}$ Corresponding author: Rosangela Zacarias Machado

Departamento de Patologia Veterinária,

Faculdade de Ciências Agrárias e Veterinárias,

Universidade Estadual Paulista - UNESP,

Via de Acesso Prof. Dr. Paulo Donato Castellane, s/n, CEP 14884-900,

Jaboticabal - SP, Brazil;

e-mail: zacarias@fcav.unesp.br
} 


\section{Introduction}

Trypanosoma evansi is a widely distributed hemoflagellate parasite that affects a wide range of animals, causing high morbidity and mortality in some species, especially horses and dogs. In Brazil, the disease caused by T. evansi and known as "Mal de Cadeiras" is considered endemic in the Pantanal region,where the parasite is found in horses, dogs, cattle, buffaloes, capybaras, and coatis (STEVENS et al., 1989; NUNES; OSHIRO, 1990; NUNES et al., 1993; FRANKE; GREINER; MEHLITZ, 1994). This trypanosomiasis is the principal protozoal disease of horses in the region, where recent outbreaks with high mortality and mortality have been reported (SILVA et al., 1995a, b), and assumes great importance since horses are indispensable to management in extensive cattle ranching, the main economic activity in the Pantanal (SILVA; BARROS; HERRERA, 1995; SEIDL; MORAES; SILVA, 1998).

The diagnosis of "Mal de Cadeiras" remains problematic and commonly used tests have important limitations (DAVISON et al., 1999). Diagnosis of trypanosomes by direct parasitological techniques is not reliable, specially for naturally occurring field cases, where parasitemias are often low and sporadic (RAE; LUCKINS, 1984; BENGALY; KANWE; DUVALLET, 1995; NANTULYA, 1994). Serological tests for circulating antibody, ELISA and IFAT, have been intensively employed, showing good sensitivity (PAYNE et al., 1991; MUKANI et al., 1992; MONZON; HOYOS; JARA, 1995). But antibody detection assays are often hampered by the lack of specifity, the result of strong cross-reactions with other pathogenic trypanosomes (DESQUENES et al., 2001; UZCANGA et al., 2002). Antigen detection ELISAs have been used in various animal species (DIALL et al., 1992; MONZON; HOYOS; JARA, 1995; KASHIWAZAKI et al., 1998). However, proper evaluation of the diagnostic parameters in these assays showed poor results (DAVISON et al., 1999).

Few studies on antigenic characterization of $T$. evansi have been undertaken (UCHE; JONES; BOID, 1993; UCHE; JONES, 1994; QUEIROZ et al., 2001) and little is known so far regarding the polypeptide recognition patterns by antibodies from different host species.

The aim of this research was to investigate the presence of T. evansi antibodies in animals from the subregion of Nhecolandia in the Pantanal Sul-mato-grossense, and to study the patterns of polypeptide recognition of a Brazilian T. evansi stock by sera from naturally infected seropositive animals and its correlation with the profile obtained by sera from experimentally infected hosts in acute and chronic stage of the infection.

\section{Material and Methods}

\section{Animals}

A total of 98 horses, 102 bovines, 55 dogs, and 32 coatis from three different properties located in the Pantanal of Nhecolandia - MS, were randomly selected for this study. Blood samples collected from the jugular vein were allowed to clot at room temperature, and then centrifuged. Serum was stored at $-20{ }^{\circ} \mathrm{C}$.
Serum samples obtained in previous studies of experimental T. evansi infection in dogs (AQUINO et al., 1999), bovines (POCHINI, 2000), coatis (HERRERA et al., 2001), and donkeys (CADIOLI, 2001) were used. Sera obtained from the experimentally infected animals before inoculation and on different days during infection were used in Western blotting and as reference negative and positive control sera in serology.

\section{Antigen preparation}

Antigens were prepared from a T. evansi stock originally isolated from a dog naturally infected in the Pantanal of Nhecolandia (AQUINO et. al, 1999). Antigenic substrate for IFAT and soluble antigen used in ELISA and Western blotting were prepared according to Aquino et al. (1999). Protein content of the soluble antigen was determined by the bicinconinic acid method (BCA Reagent Kit - Pierce Chemical Company).

\section{Serology}

Serum samples from horses, bovines, and dogs were evaluated for the presence of anti-trypanosome antibodies by enzyme linked immunosorbent assay (Ab-ELISA). Indirect fluorescent antibody test (IFAT) was used for coati sera. Both tests were carried out essentially as described by Aquino et al. (1999) and briefly described below.

ELISA: Plates were coated with 5, 10, and $15 \mu \mathrm{g}$ of soluble antigen in horse, dog, and bovine assays, respectively. Bovine, equine, and dog sera were respectively diluted 1:100, 1:200 and 1:400. Alkaline phosphatase conjugated rabbit anti-dog IgG (SIGMA A-6042), anti-horse IgG (SIGMA A-6063), and anti-bovine IgG (SIGMA A-0668) were diluted following manufacturer's instructions. All test and control sera were tested in duplicate. For determining ELISA cut-off for each species, the mean absorbance of tested sera was grouped into ELISA levels (EL), which ranged from 0 to 9 . The maximal limit of level 0 was determined by the mean absorbance of negative control sera $(n=10)$ with addition of twice the standard deviation, and subsequent levels were determined by increments of $35 \%$. Sera with EL $\geq 3$ were considered positive.

IFAT: Successive coati serum samples at dilutions from 1:40 (1:40, $1: 80,1: 160 \ldots)$ were tested. Goat anti-raccoon IgG (KPL02-32-06) fluorescein conjugate was used in 1:10 dilution. The IFAT reaction was considered positive at serum dilutions $\geq 1: 80$.

\section{SDS-PAGE}

T. evansi soluble proteins were separated by electrophoresis (Mini-Protean II, Bio-Rad) on a $8-18 \%$ gradient polyacrylamide gel in the presence of sodium dodecyl sulfate (LAEMMLI, 1970). Samples containing $18.5 \mu \mathrm{g}$ of soluble proteins were loaded into each well and a mixture of calibration proteins of molecular range between 220 and 14.3 kDa ("Rainbow," Amershan Life Science RPN 756) was included in one well during each run. All gels were run at 200 volts. 


\section{Western blotting}

Following SDS-PAGE, the polypeptides were electrophoretically transferred at $75 \mathrm{~V}$ for 3 hours from the gel to a nitrocellulose membrane by the procedure described by Towbin, Stalhelin e Gordon (1979).

Membranes were blocked for 12 hours with 5\% nonfat dry milk and 0.05\% Tween-20 in Tris buffered saline (TBS: $20 \mathrm{mM}$ Tris, $500 \mathrm{mM} \mathrm{NaCl}, \mathrm{pH} 7.5$ ).

For immuno-detection, strips of nitrocellulose containing individual runs were cut and incubated with test sera. Sera from experimentally infected animals ( $\mathrm{N}$ bovines, three donkeys, four dogs, and four coatis) were pooled for each sampling date along the acute and chronic phases of the infection. Sera from seropositive horses, bovines, dogs, and coatis from the Pantanal were evaluated individually against T. evansi antigens. Incubations were performed at room temperature. All sera were diluted 1:100 in blocking buffer ( $5 \%$ nonfat dry milk in TBS-Tween) and added to the membrane strips for 3 hours. Sera were removed and membranes were washed with blocking solution for 10 minutes, followed by two washes ( 5 minutes each) with TBS-Tween. The strips were then incubated for 90 minutes with appropriate dilution of alkaline phosphatase conjugated antibodies against horse, bovine, dog, and raccoon $\mathrm{IgG}$ as already referred to for serology. Anti- raccoon IgG (KPL 05-32-06) was used for detection of antibodies in coati sera, following the instructions of the supplier. Conjugate was removed and three washes (5 minutes each) were performed using TBS-Tween. The polypeptide bands were visualized by the addition of the enzyme substrate 5 bromo-4-chloro-3 indoyl phosphate/nitroblue tetrazolium chloride (NBT-BCIP, SIGMA B-5655). Colorimetric reactions were stopped by washing the blots in distilled water.

Sera obtained from experimentally infected animals before and after infection with $T$. evansi served as the negative and positive controls, respectively. Relative mobility of immunorecognized polypeptides was estimated from a calibration curve based on standards for mobility of proteins.

\section{Results}

\section{Serology}

Antibodies of diagnostic value were detected in sera from 16 dogs (29.1\%), 23 horses (23.5\%), and 8 coatis (25\%). None of the bovines were found positive by serology (Table 1 ).

\section{Antigenic characterization of T. evansi}

IgG antibodies to T. evansi polypeptides were first detected in serum of experimentally infected animals from 4 to 7 days after infection. The molecular weight of the $T$. evansi antigens recognized by $\mathrm{IgG}$ in experimentally infected donkeys, bovines, dogs, and coatis ranged from 160 to $15 \mathrm{kDa}$. The bands corresponding to the polypeptides of $160,88,74,66,52 / 50,48 / 46,38,32 / 30$, $27,25,20$, and $17 \mathrm{kDa}$ were more consistently and/or more intensely stained. The polypeptides of 74 and $66 \mathrm{kDa}$ were labeled as early as 4 to 5 days after experimental infection by bovine, donkey, and dog antibodies. As the infection progressed increasing numbers of trypanosome antigens were recognized, with the staining of most individual bands becoming more evident. Differences were observed among studied species in the recognition pattern and intensity of labeling of some polypeptides (Table 2 and Figure 1). The polypeptides of 74, 27, and $20 \mathrm{kDa}$ were recognized by dog, donkey, and bovine sera, while those of 25 and $17 \mathrm{kDa}$ were identified by donkeys and dogs; the 88,52 , and $32 \mathrm{kDa}$ polypeptides were common to bovines and donkeys and the $160 \mathrm{kDa}$ band was recognized by dogs and coatis. The polypeptides of $66,48-46$ and $38 \mathrm{kDa}$ were identified by sera from experimentally infected bovines, donkeys, dogs, and coatis. The 48-46 and $38 \mathrm{kDa}$ bands were mainly recognized in chronic phase of infection.

Antibodies of naturally infected animals from the Pantanal recognized the same polypeptides labeled by antibodies of the corresponding experimentally infected species, with variations in the number of antigens recognized occurring between animals (Figure 2). Four lower molecular weight proteins (32, 30, 27, and $25 \mathrm{kDa})$ that were detected during chronic phase of experimental infection in donkeys were not recognized by sera from 5 of 23 seropositive horses from the Pantanal. Five out of 29 seropositive naturally infected dogs recognized three polypeptides $(88,32$, and $30 \mathrm{kDa})$ not labeled by pooled dog sera collected along experimental infection. Differences in immunorecognition profile were more

Table 1. Detection of anti-T. evansi antibodies (number and percentage of positive sera) in serum samples of horses, dogs, and coatis from Nhecolândia Pantanal, MS.

\begin{tabular}{lccc}
\hline \multirow{2}{*}{ Host species } & Test & \multicolumn{2}{c}{ Positive animals } \\
\cline { 3 - 4 } & & n & \% \\
\hline Horses & (Ab - ELISA) & $23(98)$ & 23.4 \\
Dogs & (Ab - ELISA) & $16(55)$ & 29.0 \\
Coatis & (IFAT) & $8(32)$ & 25.0 \\
\hline
\end{tabular}

Table 2. T. evansi polypeptides recognized by antibodies of experimentally and naturally infected bovines, donkeys/horses, dogs, and coatis by Western blotting.

\begin{tabular}{|c|c|c|c|c|c|c|c|c|}
\hline \multirow[t]{2}{*}{$\begin{array}{c}\text { PM } \\
(\mathbf{k D a})\end{array}$} & \multicolumn{2}{|c|}{ Bovine } & \multicolumn{2}{|c|}{$\begin{array}{c}\text { Donkey/ } \\
\text { Horse }\end{array}$} & \multicolumn{2}{|c|}{ Dog } & \multicolumn{2}{|c|}{ Coati } \\
\hline & $\mathbf{E}$ & $\mathbf{N}^{*}$ & $\mathbf{E}$ & $\mathbf{N}$ & E & $\mathbf{N}$ & E & $\mathbf{N}$ \\
\hline 160 & $\mathrm{x}$ & - & - & - & $\mathrm{x}$ & $\mathrm{O}$ & $\mathrm{X}$ & o \\
\hline 88 & $\mathrm{x}$ & - & $\mathrm{x}$ & - & - & o & - & - \\
\hline 74 & $\mathrm{X}$ & - & $\mathrm{x}$ & o & $\mathrm{x}$ & $\mathrm{O}$ & - & - \\
\hline 66 & $\mathrm{X}$ & - & $\mathrm{x}$ & o & $\mathrm{X}$ & o & $\mathrm{X}$ & o \\
\hline $52 / 50$ & $\mathrm{X}$ & - & $\mathrm{x}$ & O & - & - & - & - \\
\hline $48 / 47 / 46$ & $\mathrm{x}$ & - & $\mathrm{x}$ & o & $\mathrm{x}$ & o & $\mathrm{x}$ & o \\
\hline 38 & $\mathrm{x}$ & - & $\mathrm{x}$ & o & $\mathrm{x}$ & o & $\mathrm{x}$ & o \\
\hline $32 / 30$ & $\mathrm{X}$ & - & $\mathrm{x}$ & o & - & o & - & o \\
\hline 27 & $\mathrm{x}$ & - & $\mathrm{x}$ & o & $\mathrm{x}$ & o & - & - \\
\hline 25 & - & - & $\mathrm{x}$ & $\mathrm{O}$ & $\mathrm{x}$ & o & - & $\mathrm{O}$ \\
\hline 20 & $\mathrm{x}$ & - & $\mathrm{x}$ & o & $\mathrm{x}$ & $\mathrm{O}$ & - & - \\
\hline 17 & - & - & $\mathrm{x}$ & - & $\mathrm{x}$ & $\mathrm{o}$ & - & - \\
\hline
\end{tabular}

$\mathrm{E}=$ Experimentally infected; ${ }^{*}$ All cattles were negatives. $\mathrm{N}=$ Naturally infected. 
evident between individual free-ranging coatis. Three of them recognized only the $48 \mathrm{kDa}$ polypeptide and a band corresponding to the polypeptides from 110 to $160 \mathrm{kDa}$. The $66 \mathrm{kDa}$ antigen was labeled by sera from two animals. Serum from one free-ranging coati, however, recognized additionally the polypeptides of 30,25 , and $23 \mathrm{kDa}$, not labeled by antibodies from experimentally infected coatis.

\section{Discussion}

In the present study, five major polypeptides with apparent molecular weights $88,74,66,32$, and $27 \mathrm{kDa}$ recognized by antibodies of experimental animals, appear to correspond to the $85,75.5,67,32.4$, and $28 \mathrm{kDa}$ antigens of $T$. evansi revealed by sera of rabbits experimentally infected with an Indonesian stock of the parasite (UCHE; JONES; BOID, 1993). Similarly, the polypeptides of $88,74,66,46,32$, and $17 \mathrm{kDa}$ recognized in our study probably correspond to $86,73,6846,32$, and $17 \mathrm{kDa}$ components labeled by antibodies of horses experimentally infected with a Venezuelan isolate of T. evansi (UZCANGA et al., 2002). The increasing numbers of polypeptides recognized by experimental infected bovines, donkeys, dogs, and coatis with the increasing duration of infection in the present study is in agreement with earlier observations made in experimentally infected rabbits (UCHE; JONES; BOID, 1993). The greater number of polypeptides detected in chronic phase of infection is probably due to the release of internal antigens after parasite destruction by variable surface glycoprotein (VSG) specific antibodies. Our results differ however from those of Queiroz et al. (2001), who observed no variation in polypeptide profiles along the course of experimental infection in rats with Brazilian isolates of T. evansi.

Differences were observed among studied species in the recognition pattern and intensity of labeling of some polypeptides. The polypeptides of $66,48-46$, and $38 \mathrm{kDa}$ were identified by sera from all experimentally infected hosts in this research.

The analysis of cell membrane preparations of seven different stocks of T. evansi isolated from buffaloes, equines, or camels in India revealed polypeptides with molecular weight ranging from 48.4 to 80.2 kDa (SINGH, V.; SINGH, A.; CHHABRA, 1995).
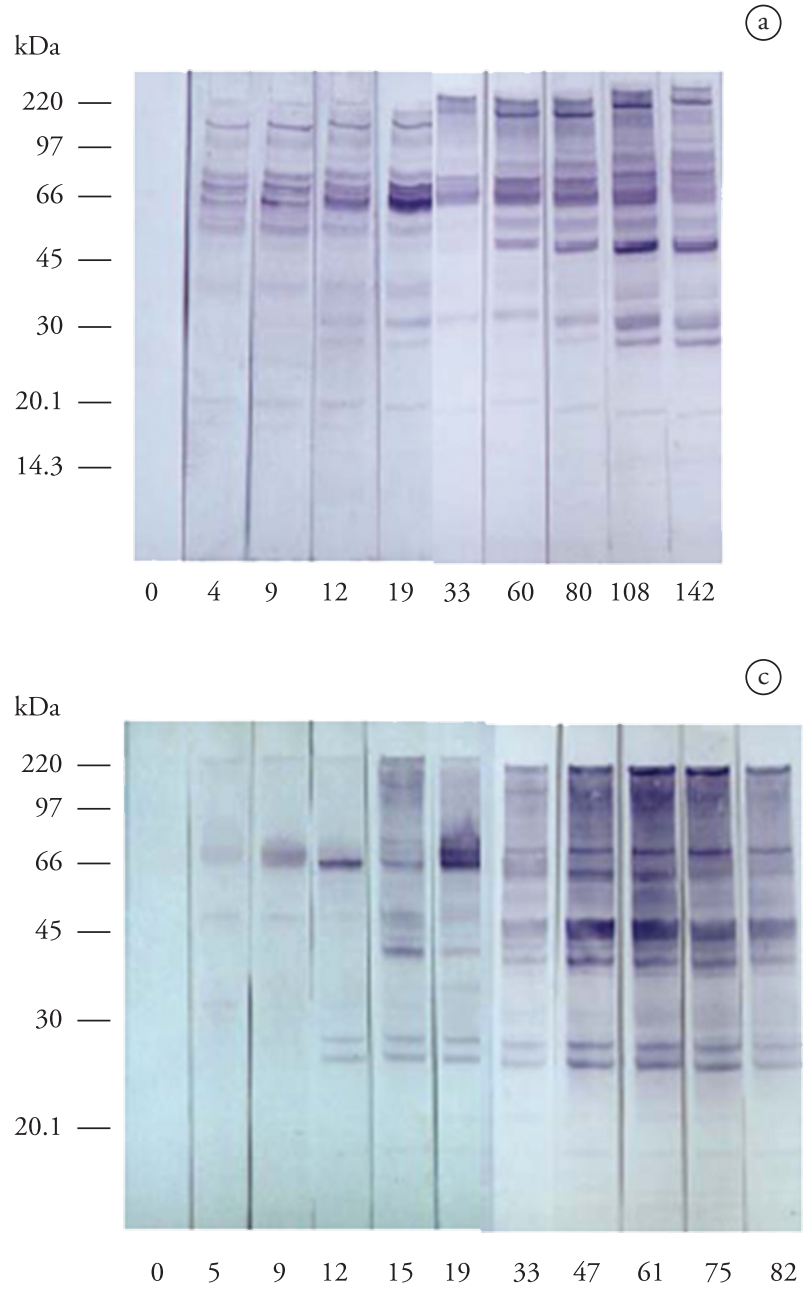

$\mathrm{kDa}$

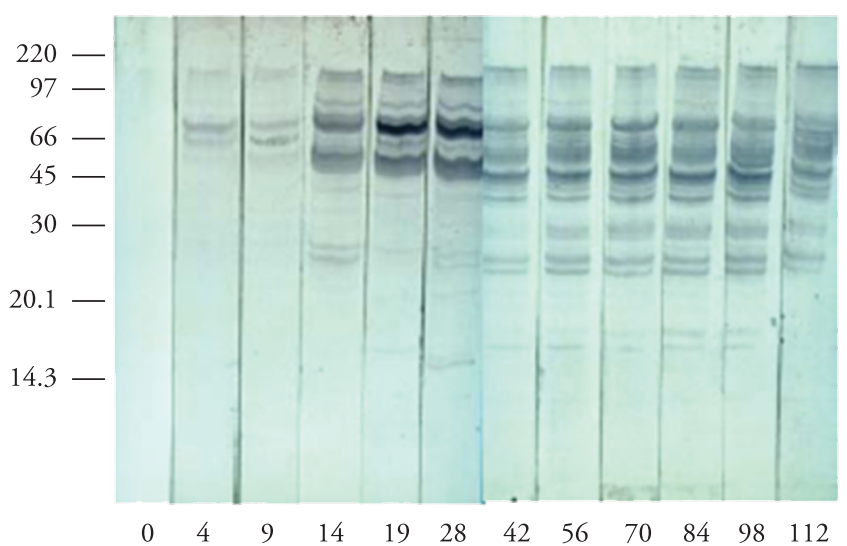

(d)

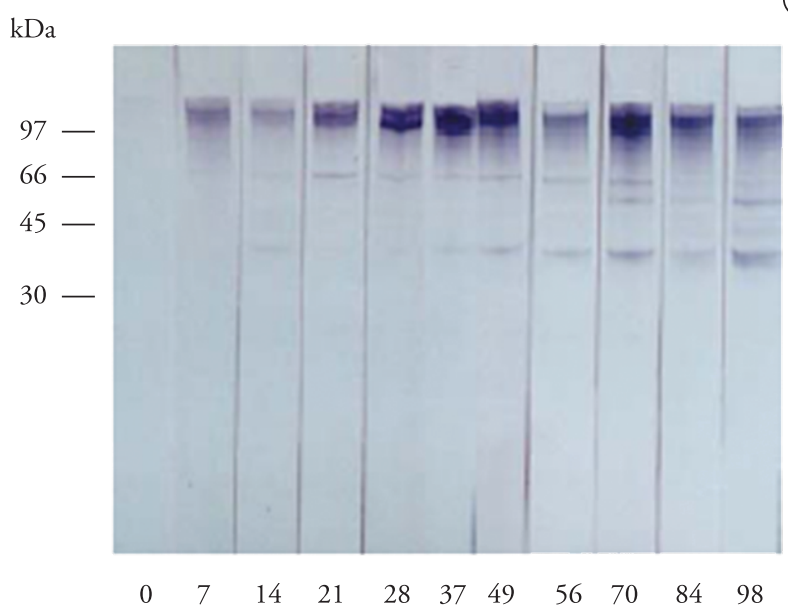

Figure 1. Immunoreactivity of polled sera from experimentally infected bovines (a), horses (b), dogs (c), and coatis (d) obtained before and in different days along infection period. Labels below each blot: "0" indicates sera taken before experimental inoculation, and consecutive numbers indicate days after infection when sera were collected. 

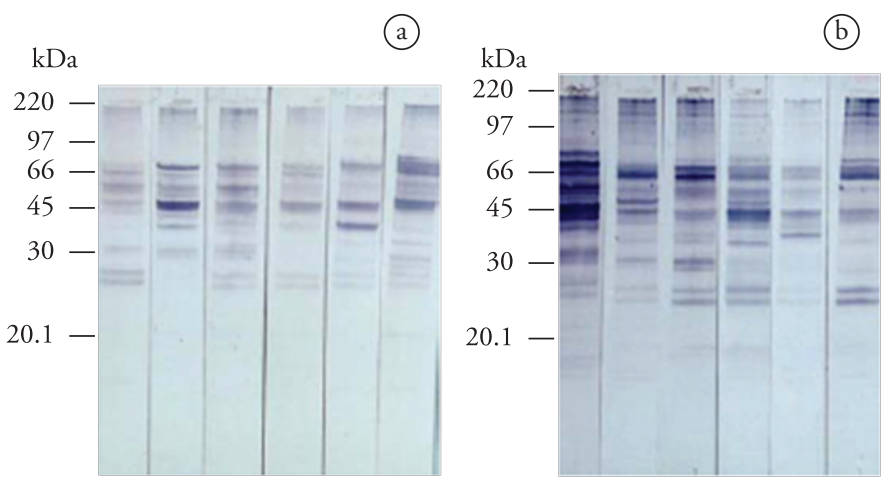

(b)
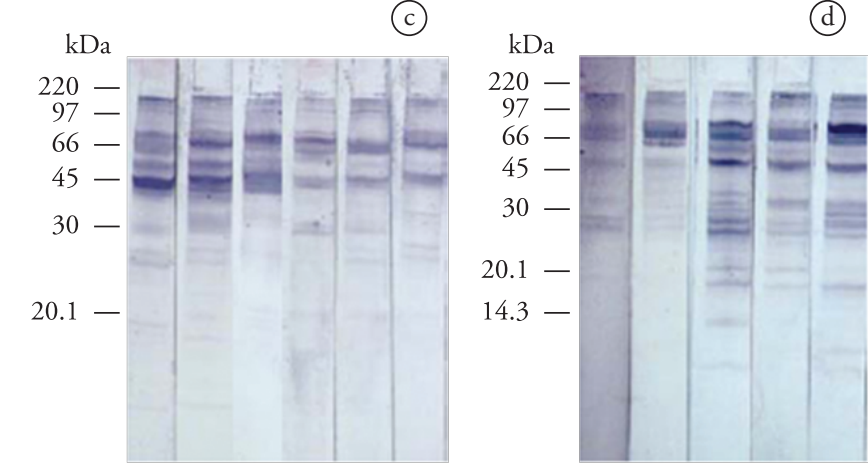

(f)
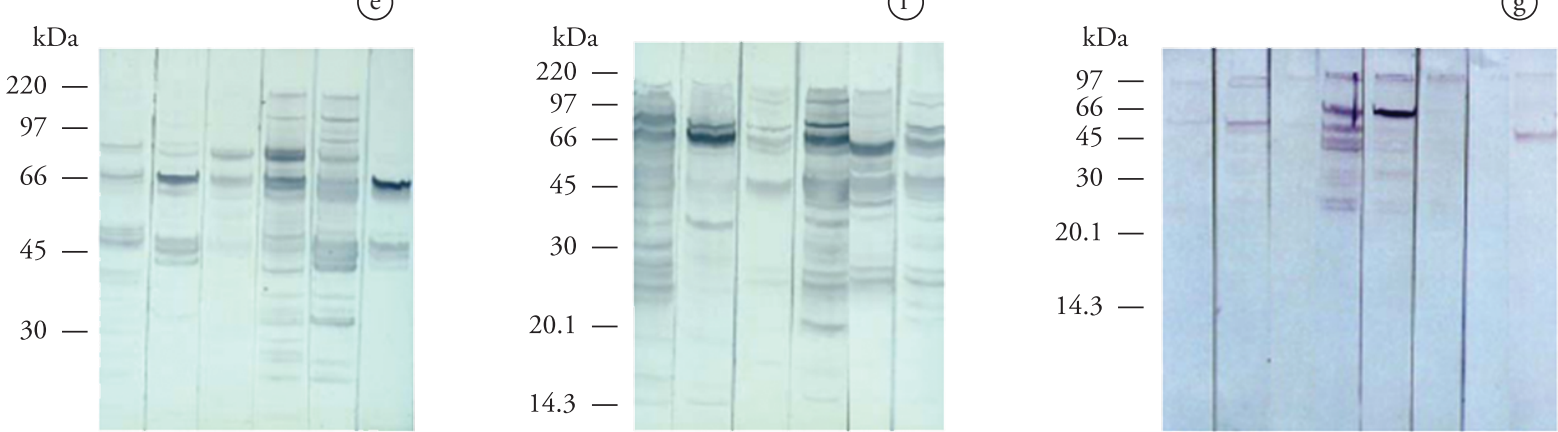

Figure 2. Immunoreactivity of individual sera from horses (blots a, b, c, and d), dogs (blots e and f), and coatis (blot g) seropositive for T. evansi from the sub region of Nhecolândia, in the Pantanal Sul-Mato-Grossense.

Major polypeptides recognized by experimental animals in our study were those with 74 to $48-46 \mathrm{kDa}$ and consequently within the molecular weight range of surface antigens. Recently, Laha and Sasmal, 2008 showed 11 immunogenic proteins using hyperimmune sera from buffalo, horse and cattle, but in naturally T. evansi infected immune sera of horse detected 19 immunogenic proteins. Five common immunogenic proteins of relative molecular weight ranged 61-64, 44-47, 33-34, 25-26 and 14-16 kDa using hyperimmune and immune sera. The band corresponding to the $66 \mathrm{kDa}$ polypeptide was firstly recognized as early as five days after infection by all host species in the present study and remained continuously labeled during the experimental period. Besides being revealed by antibodies from all experimental animals, the $66 \mathrm{kDa}$ polypeptide was also recognized by sera of all naturally infected horses and dogs and of most free-ranging coatis. A polypeptide with similar mass $(67 \mathrm{kDa})$ previously identified as a surface antigen of T. evansi (UCHE; ROSS; JONES, 1992) was also consistently recognized by rabbits experimentally infected (UCHE; JONES; BOID, 1993) and showed to be associated with protection (UCHE et al., 1994). The $66 \mathrm{kDa}$ polypeptide detected in our experiment may correspond to the $64 \mathrm{kDa}$ polypeptide recognized in a Venezuelan stock of the parasite by sera of experimentally infected horses (UZCANGA et al., 2002). The same study, however, showed that this polypeptide exhibited cross-reactivity with $T$. vivax. This finding is of concern since T. vivax also occurs in the Brazilian Pantanal (SILVA et al.,1996), which limits the possibility of utilizing this polypeptide as a tool for specific diagnosis of T. evansi infection in the region.

The 48-46 and $38 \mathrm{kDa}$ bands showed progressive increase in intensity of staining as infection progressed and were consistently marked by antibodies of experimental species in chronic phase of the disease. Besides being identified by all experimentally infected hosts, the $48-46 \mathrm{kDa}$ polypeptide was identified by antibodies from all seropositive animals from the Pantanal. The consistent serorecognition of this protein would indicate it as a good candidate to be assessed for diagnosis purposes. However, further studies must evaluate additional parameters related to the proposed antigen before it may be considered a reliable tool in serodiagnosis of T. evansi infection.

Even though the polypeptides recognized by seropositive animals from the Pantanal were the same polypeptides labeled by antibodies of the corresponding experimentally infected specie, we observed variation in the number of components recognized among naturally infected animals of the same species, even within the same farm. Comparisons between polypeptides recognized by naturally infected animals and the profile obtained from the corresponding experimentally infected hosts during acute and chronic phase of the disease allows evaluating the stage of the infection of field seropositive animals. Individual differences observed in the number and staining intensity of recognized polypeptides indicate seropositive animals in different stages of the disease in the same property.

Additional detailed studies using Western blotting in characterization of different stocks of $T$. evansi by antibodies of various host species may enhance the understanding of the host-parasite relationship and give some insight into the pathogenicity and immunogenicity of this parasite. Specific parasite polypeptides identified could be further evaluated for use in the diagnosis of this trypanosomiasis. 


\section{Acknowledgements}

To Rosângela Yamazaki de Andrade for technical assistance. This work was supported by Fundação de Amparo a Pesquisa do Estado de São Paulo (FAPESP, no 2001/ 08097-6).

\section{References}

AQUINO, L. P. C. T. et al. Clinical, parasitological and immunological aspects of experimental infection with Trypanosoma evansi in dogs. Memórias do Instituto Oswaldo Cruz, v. 92, n. 2, p. 255-260, 1999.

BENGALY, Z.; KANWE, A. B.; DUVALLET, G. Evaluation of an antigen detection-ELISA test for the diagnosis of trypanosomiasis in naturally infected cattle. Tropical Medicine and Parasitology, v. 46, p. 284-286, 1995.

CADIOLI, F. A. Infecção experimental em jumentos (Equus asinus) com Trypanosoma evansi Steel, 1885. 142 p. Dissertação (Mestrado) - Faculdade de Ciências Agrárias e Veterinárias, Universidade Estadual Paulista, Jaboticabal, 2001.

DAVISON, H. C. et al. Evaluation of antigen detection and antibody detection tests for Trypanosoma evansi infections of buffaloes in Indonesia. Epidemiology and Infection, v. 123, p. 149-155, 1999.

DESQUENES, M. et al. The analysis of the cross-reactions occurring in the antibody-ELISA for the detection of trypanosomes can improve identification of the parasite species involved. Annals of Tropical Medicine and Parasitology, v. 95, p. 141-155, 2001.

DIALL, O. et al. Evaluation of mono and polyclonal antibody-based antigen detection immunoassays for diagnosis of Trypanosoma evansi infection in the dromedary camel. Revue d Élevage et de Medecine Veterinaire des Pays Tropicaux, v. 45, p. 149-153, 1992.

FRANKE, C. R.; GREINER, M.; MEHLITZ, D. Investigation on naturally occurring Trypanosoma. evansi infections in horses, cattle, dogs and capybaras (Hydrochaeris hydrochaeris) in Pantanal de Poconé (Mato Grosso, Brazil). Acta Tropica, v. 58, p. 159-169, 1994.

HERRERA, H. M. et al. Trypanosoma evansi experimental infection in the South American coati (Nasua nasua): clinical, parasitological and humoral immune response. Veterinary Parasitology, v. 102, p. 209-216, 2001.

KASHIWAZAKI, Y. et al. Haemoparasite infections in newly introduced dairy cattle in Loei Province, Thailand: Trypanosoma evansi antigen levels by ELISA referring to abortion. Veterinary Parasitology, v. 80, p. 99-109, 1998.

LAEMMLI, U. K. Cleavage of structural proteins during assembly of head bacteriophage T4. Nature, v. 227, p. 680-685, 1970.

LAHA, R.; SASMAL, N. K. Characterization of immunogenic proteins of Trypanosoma evansi isolated from three different Indian hosts using hyperimmune sera and immune sera. Research in Veterinary Science, v. 85, n. 3, p. 534-539, 2008.

MONZON, C. M.; HOYOS, C. B.; JARA, G. A. Outbreaks of equine tripanosomiasis caused by Trypanosoma evansi in Formosa Province, Argentine. Revue Scientifique et Technique, v. 14, p. 753-759, 1995.

MUKANI, W. O. et al. Comparison of antibody and antigen-detection enzyme immunoassays for the diagnosis of Trypanosoma evansi infections in camels. Veterinary Parasitology, v. 45, p. 231-240, 1992.
NANTULYA, V. M. Swzatex: a simple agglutination antigen test for diagnosis of Trypanosoma evansi infections (Surra). Tropical Medicine and Parasitology, v. 40, p. 415-418, 1994.

NUNES, V. L. B.; OSHIRO, E. T. Trypanosoma evansi in the coati from the Pantanal region of Mato Grosso do Sul State, Brazil. Transactions of the Royal Society of Tropical Medicine and Hygiene, v. 84, p. 692, 1990 .

NUNES, V. L. B. et al. Investigaçáo epidemiológica sobre Trypanosoma (Trypanozoon) evansi no pantanal sul-mato-grossense. Estudo de reservatórios. Revista Brasileira de Parasitologia Veterinária, v. 2, n. 1, p. 41-44, 1993.

PAYNE, R. C. et al. Trypanosoma evansi infection in cattle, buffaloes and horses in Indonesia. Veterinary Parasitology, v. 38, p. 109-119, 1991.

POCHINI, L. R. Infecçáo experimental em bovinos com Trypanosoma evansi Steel, 1885 (Sarcomastigophora: Trypanosomatidae). $102 \mathrm{f}$. Dissertação (Mestrado em Clínica Médica Veterinária) - Faculdade de Ciências Agrárias e Veterinárias, Universidade Estadual Paulista "Júlio de Mesquita Filho", Jaboticabal, 2000.

QUEIROZ, A. O. et al. Specific antibody levels and antigenic recognition of wistar rats inoculated with distinct isolates of Trypanosoma evansi. Memórias do Instituto Oswaldo Cruz, v. 96, n. 7, p. 965-972, 2001.

RAE, P. F.; LUCKINS, A. G. Detection of circulating trypanosomal antigens by enzyme immunoassay. Annals of Tropical Medicine and Parasitology, v. 7, n. 6, p. 587-596, 1984.

SEIDL, A. F.; MORAES, A. S.; SILVA, R. A. M. S. A financial analysis of alternative strategies for treatment of Trypanosoma evansi in the Brazilian Pantanal. Journal of Preventive Veterinary Medicine, v. 33, n. 1, p. 219-243, 1998.

SILVA, R. A. M. S.; BARROS, A. T. M.; HERRERA, H. M. Trypanosomosis outbreaks due to Trypanosoma evansi in the Pantanal, Brazil. A preliminary approach on risk factors. Revue $\boldsymbol{d}$ Élevage et de Medecine Veterinaire des Pays Tropicaux, v. 48, n. 4, p. 315-319, 1995.

SILVA, R. A. M. S. et al. Pathogenesis of Trypanosoma evansi infection in dogs and horses: haematological and clinical aspects. Ciência Rural Santa Maria, v. 25, n. 2, p. 223-238, 1995a.

SILVA, R. A. M. S. et al. Outbreak of trypanosomosis due to Trypanosoma evansi in horse from Pantanal Mato-grossense, Brazil. Veterinary Parasitology, v. 48, p. 1-5, 1995b.

SILVA, R. A. M. S. et al. Outbreak of trypanosomiais due to Trypanosoma vivax (Ziemann, 1905) in bovines of the Pantanal, Brazil. Memórias do Instituto Oswaldo Cruz, v. 9, n. 5, p. 561-562, 1996.

SINGH, V.; SINGH, A.; CHHABRA, M. B. Polypeptide profiles and antigenic characterization of cell membrane and flagellar preparations of different stocks of Trypanosoma evansi. Veterinary Parasitology, v. 59, p. 269-279, 1995.

STEVENS, J. R. et al. Isoenzyme characterization of Trypanosoma evansi isolated from capybaras and dogs in Brazil. Acta Tropica, v. 46, p. 213-222, 1989.

TOWBIN, H.; STALHELIN, T.; GORDON, J. Electrophoretic transfer of proteins from polyacrylamide gels to nitrocellulose sheets: procedure and some applications. Proceedings of the National Academy of Science, v. 76, p. 4350-4354, 1979. 
UCHE, U. E.; ROSS, C. A.; JONES, T. W. Identification of the surface components of Trypanosoma evansi. Research in Veterinary Science, v. 53, p. 252-253, 1992.

UCHE, U. E.; JONES, T. W. Protection conferred by Trypanosoma evansi infection against homologous and heterologous trypanosoma challenge in rabbits. Veterinary Parasitology, v. 52, p. 21-35, 1994.
UCHE, U. E.; JONES, T. W.; BOID, R. Class- specific antibody response in rabbits experimentally infected with Trypanosoma evansi. Tropical Medicine and Parasitology, v.4, p.27-31, 1993.

UZCANGA, G. et al. Purification of a $64 \mathrm{kDa}$ antigen from Trypanosoma evansi that exhibits cross-reactivity with Trypanosoma vivax. Parasitology, v. 124, p. 287-299, 2002. 